\title{
Eco-Geographical, Morphological and Molecular Characterization of a Collection of the Perennial Endemic Species Medicago tunetana (Murb.) A.W. Hill (Fabaceae) from Tunisia
}

\author{
Yosr Ferchichi ${ }^{1,2, *(\mathbb{D}}$, Anis Sakhraoui ${ }^{1,3,4}{ }^{\mathbb{D}}$, Hela Belhaj Ltaeif ${ }^{1,2}$, Yosr Ben Mhara ${ }^{1,2}$, Mohamed Elimem ${ }^{1}$ (D) \\ M'barek Ben Naceur $^{5}$, Zeineb Ghrabi-Gammar ${ }^{2,6}$ and Slim Rouz ${ }^{1}$
}

1 Laboratory of Agriculture Production Systems and Sustainable Development (LR03AGR02), Department of Agricultural Production, Higher School of Agriculture of Mograne, University of Carthage,

Mograne-Zaghouan 1121, Tunisia; anis.sakhraoui@esakef.u-jendouba.tn (A.S.);

belhajhela1@gmail.com (H.B.L.); yosrmhara13@gmail.com (Y.B.M.);

mohammed.elimem123@gmail.com (M.E.); slim.rouz@esamg.u-carthage.tn (S.R.)

2 National Institute of Agronomy of Tunis, University of Carthage, Tunis 1082, Tunisia; zghrabi@yahoo.fr

3 Higher School of Agriculture of Kef, University of Jendouba, Le Kef 7119, Tunisia

4 Departamento de Biología Vegetal y Ecología, Universidad de Sevilla, Apartado 1095, 41080 Sevilla, Spain

5 National Gene Bank of Tunisia, Boulevard Leader Yasser Arafat Z. I. Charguia 1, Tunis 1080, Tunisia; nour3alanou@yahoo.com

6 Laboratoire de Recherche Biogéographie, Climatologie Appliquée et Dynamiques Environnementales

check for

updates

Citation: Ferchichi, Y.; Sakhraoui, A.; Ltaeif, H.B.; Ben Mhara, Y.; Elimem, M.; Ben Naceur, M.; Ghrabi-Gammar, Z.; Rouz, S. Eco-Geographical, Morphological and Molecular

Characterization of a Collection of the Perennial Endemic Species Medicago tunetana (Murb.) A.W. Hill (Fabaceae) from Tunisia. Plants 2021, 10, 1923. https://doi.org/10.3390/plants10091923

Academic Editors: Emmanuele Farris and Javier López-Alvarado

Received: 5 August 2021

Accepted: 8 September 2021

Published: 15 September 2021

Publisher's Note: MDPI stays neutral with regard to jurisdictional claims in published maps and institutional affiliations.

Copyright: (C) 2021 by the authors Licensee MDPI, Basel, Switzerland. This article is an open access article distributed under the terms and conditions of the Creative Commons Attribution (CC BY) license (https:/ / creativecommons.org/licenses/by/ $4.0 /)$. (Bi CADE 18ES13), Faculté des Lettres des Arts et des Humanités de Manouba, Campus Universitaire de la Manouba, Université de la Manouba, Manouba 2010, Tunisia

* Correspondence: yosr.ferchichi91@gmail.com

Abstract: In order to characterize and conserve the endemic pastoral species Medicago tunetana, many prospecting missions were carried out in mountainous regions of the Tunisian ridge. Twentyseven eco-geographical and morphological traits were studied for six M. tunetana accessions and followed by molecular analysis using seven Simple Sequence Repeat (SSR). Only five markers were polymorphic and reproductible in the six M. tunetana populations. A total of 54 alleles were observed with an average of 10.8 bands/primer/genotype. Mean Polymorphism Information Content (PIC), Nei gene diversity (h) Shannon's information index (I) indicated the high level of polymorphism. The generated dendrogram with hierarchical UPGMA cluster analysis grouped accessions into two main groups with various degree of subclustring. All the studied accessions shared $57 \%$ of genetic similarity. Analysis of variance showed high significant difference between morphological traits among M. tunetana populations where MT3 from Kesra showed different morphological patterns regarding leaf, pod and seeds traits. Canonical correspondence analysis (CCA) showed two principal groups of $M$. tunetana populations based on potassium, total and active lime contents in soil. Our results suggest that SSR markers developed in $M$. truncatula could be a valuable tool to detect polymorphism in M. tunetana. Furthermore, the studied morphological markers showed a large genetic diversity among $M$. tunetana populations. This approach may be applicable for the analysis of intra specific variability in M. tunetana accessions. Our study could help in the implementation of an effective and integrated conservation programs of perennial endemic Medicago.

Keywords: characterization; conservation programs; genetic diversity; SSRs markers; polymorphism

\section{Introduction}

Tunisia has a large and wealthy forage and pasture biodiversity. According to Abdelguerfi and Abdelguerfi-Laouar [1], there are more than 960 pasture legumes species, 336 of which are Mediterranean endemic. However, native and endemic Tunisian pasture plants are endangered due to many factors among which overgrazing [2] and natural habitat loss into introduction of intensive farming and which are the most important ones $[3,4]$. Thereby, conservation and valorisation of pasture and forage genetic resources 
have become key tasks, especially in Tunisian Dorsal regions where pastoralism is an important genetic loss drivers. However, pasture genetic resources in Tunisia are still less developed, despite the fact that they can enrich the Gene Bank and include many varieties in breeding [5].

Lucerne (Medicago sativa L.) is also known as queen forage alfalfa [6] thanks to its ecological attributes by avoiding erosion phenomena [3], and its wide agronomic assets by way of its protein and nitrogenous matter contents [7,8]. Perennial species of Medicago genus have an essential role in the economic sustainability of crop-livestock systems [9]. Nevertheless, alfalfa productivity is limited by some abiotic stress such as salinity $[10,11]$. Medicago tunetana (Murb.) A.W. Hill is a perennial C3 species native to Algeria and Tunisia thriving in calcareous mountains of Western North and Midwest regions of Tunisia [12]. Tunisian alfalfa has many interested eco-physiological assets such as drought tolerance, winter hardiness and calcareous soil tolerance; this genetic resource has been unstudied so far and threatened to disappear. Furthermore, the efficient management of this pasture plant species in its native regions of the Tunisian ridge may contribute in the agro-pastoral systems development. The plant breeding for the fodder crops like alfalfa is of a high importance especially for the farming system sustainability [9]. For an optimal valorisation, it is necessary to conserve, evaluate and estimate the genetic and morphological variation of $M$. tunetana and to determine the relationship within this endemic species and cultivated alfalfa. In fact, there is an ambiguity in M. tunetana taxonomy; it is considered as a subspecies of M. sativa [13-15]. However, and according to other authors, M. tunetana is classified as an independent species [16-18].

Molecular characterization has become the most efficient and reliable tool for studies of the genetic diversity between populations and species as well thanks to its environment independency $[19,20]$. In fact, it is not influenced by the stage of plant development facilitating genetic resources management within Gene Bank [21]. Molecular markers are complementary to morphological and biochemical markers [22]. Several studies have been realized on the genetic diversity of Medicago genotypes using different markers such as AFLP [23,24], RAPD [25,26], RFLP [27,28] and SSR [29-32]. The microsatellites as polymorphic DNA markers have been widely employed in molecular studies thanks to their facility and efficiency for population genetic analysis [33-35] while, using SSR markers for genetic variability within perennial Medicago genotypes had not been very developed. Diwan et al. [36] are the first authors to demonstrate the use of SSRs to characterize genetic diversity and to analyse the genetic relationships among Medicago genotypes as well. Cholastova and Knotova [30] indicated that the genetic diversity estimation of Medicago genotypes could be obtained even with only three SSR markers. Furthermore, 107 SSRs identified in the EST database of Medicago truncatula Gaaertn. was mapped also in M. sativa [37].

In order to study the M. tunetana collection, an ecological and edaphic characterization of different prospected sites was realized and followed by morphological and molecular characterization for seven accessions of $M$. tunetana and one variety of $M$. sativa used as a reference. For the molecular characterization, seven microsatellites markers were used in order to estimate the genetic diversity among $M$. tunetana local genotypes and to analyse the genetic relationship between M. tunetana and M. sativa.

\section{Results}

\subsection{Ecology of M. tunetana Sites}

$M$. tunetana was recorded in several new sites in the Tunisian dorsal region that were not mentioned in relevant flora (Figure 1). These sites are characterized by a large bioclimatic zone differences ranging from a sub-humid with cool winter at Sekiet Sidi Youssef to a medium semi-arid at Kasserine sites (Table 1). M. tunetana generally grows at the canopy of Pinus halepensis Mill. plantations characterized by a high level of organic matter (OM) in the soil that can reach more than 6\% like for MT3 and MT4 soils in Kesra and Sekiet Sidi Youssef with an average of 8.6 and $6.72 \%$ of OM respectively. The statistical 
analysis concerning edaphic parameters showed a significant difference at $p<0.05$. In fact, two types of soil are registered: a heavy soil for MT2 and MT7 in Makthar and El Ayoun with an average of 37.2 and $37.88 \%$ of clay content respectively and a sandy soil for all other prospected sites. The values of soil $\mathrm{pH}$ in this study ranged from 7.2 to 8.36 indicating an alkaline nature of soil for all M. tunetana sites (Table 1). On the other hand, the total limestone and active limestone content demonstrated that all sites are a calcareous soil especially for the MT2 soil from Makthar with a rate of $30.7 \%$ of active limestone in the soil. The analysis of potassium (K) content in soil was measured and the statistical analysis showed a significant $K$ content differences which is ranging between 38 ppm for MT1 from Bargou to 297 ppm for MT3 from Kesra.

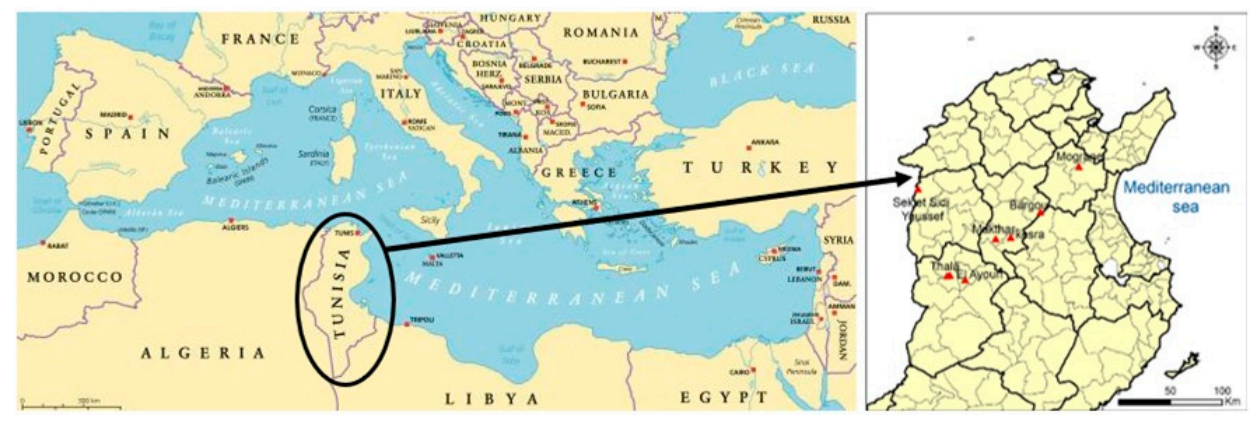

Figure 1. The geographical localization of the eight M. tunetana and M. sativa accessions [legend: Bargou: MT1; Makthar: MT2; Kesra: MT3; Sekiet Sidi Youssef: MT4; Thala: MT5-MT6; El Ayoun: MT7; Mograne: MS1].

Table 1. Eco-geographical variables for different studied accessions of $M$. tunetana. Means with the same letters are not significantly different (ANOVA, Tukey test at $p<0.05$ ); nd: not determined.

\begin{tabular}{|c|c|c|c|c|c|c|c|c|c|}
\hline $\mathbf{N}^{\circ}$ & $\begin{array}{l}\text { Eco-Geographical } \\
\text { Factors }\end{array}$ & MT1 & MT2 & MT3 & $\begin{array}{l}\text { Accessions } \\
\text { MT4 }\end{array}$ & MT5 & MT6 & MT7 & MS1 \\
\hline 1 & Origin & $\begin{array}{l}\text { Siliana, } \\
\text { Bargou }\end{array}$ & $\begin{array}{l}\text { Siliana, } \\
\text { Makthar }\end{array}$ & $\begin{array}{l}\text { Siliana, } \\
\text { Kesra }\end{array}$ & $\begin{array}{l}\text { Kef, Sekiet } \\
\text { Sidi Youssef }\end{array}$ & $\begin{array}{l}\text { Kasserine, } \\
\text { Thala }\end{array}$ & $\begin{array}{c}\text { Kasserine, } \\
\text { Thala }\end{array}$ & $\begin{array}{l}\text { Kasserine, } \\
\text { El Ayoun }\end{array}$ & $\begin{array}{l}\text { Zaghouan, } \\
\text { Mograne }\end{array}$ \\
\hline 2 & Latitude (dms) & $36^{\circ} 2^{\prime} 47.15^{\prime \prime}$ & $35^{\circ} 49^{\prime} 43.77^{\prime \prime}$ & $35^{\circ} 49^{\prime} 43.774^{\prime \prime}$ & $36^{\circ} 14^{\prime} 32.532^{\prime \prime}$ & $35^{\circ} 30^{\prime} 39.39^{\prime \prime}$ & $35^{\circ} 29^{\prime} 5.55^{\prime \prime}$ & $35^{\circ} 20^{\prime} 50.42^{\prime \prime}$ & $36^{\circ} 42^{\prime} 82.72^{\prime \prime}$ \\
\hline 3 & Longitude (dms) & $9^{\circ} 40^{\prime} 34.32^{\prime \prime}$ & $9^{\circ} 21^{\prime} 28.38^{\prime \prime}$ & $9^{\circ} 21^{\prime} 28.205^{\prime \prime}$ & $8^{\circ} 22^{\prime} 8.291^{\prime \prime}$ & $8^{\circ} 42^{\prime} 58.45^{\prime \prime}$ & $8^{\circ} 44^{\prime} 30.34^{\prime \prime}$ & $8^{\circ} 34^{\prime} 31.08^{\prime \prime}$ & $10^{\circ} 09^{\prime} 20.49^{\prime \prime}$ \\
\hline 4 & Altitude (m) & 523 & 868 & 1010 & 899 & 1003 & 1041 & 903 & 156 \\
\hline 5 & Bioclimatic zone & SSACW & SSACW & SSACW & SHCW & MSACW & MSACW & MSACW & SSACW \\
\hline 6 & Rainy days (In no) & 63.44 & 58.50 & 61.84 & 59.52 & 46.08 & 84.46 & 54.83 & 85.68 \\
\hline 7 & $\begin{array}{c}\text { Annual precipitation } \\
\qquad(\mathrm{mm})\end{array}$ & 522.50 & 468.73 & 494.89 & 464.80 & 340.83 & 327 & 299 & 415.7 \\
\hline 8 & Texture & Clay & $\begin{array}{l}\text { Silty clay } \\
\text { loam }\end{array}$ & $\begin{array}{l}\text { Silty clay } \\
\text { loam }\end{array}$ & Silty clay & Clay & Clay & $\begin{array}{l}\text { Silty clay } \\
\text { loam }\end{array}$ & nd \\
\hline 9 & Fine silt (\%) & $19.85^{b}$ & $23.49^{\mathrm{c}}$ & $23.32^{c}$ & $26.28^{d}$ & $20.05^{b}$ & $17.95^{\mathrm{a}}$ & $26.06^{\mathrm{d}}$ & nd \\
\hline 10 & Coarse silt (\%) & $2.55^{\mathrm{a}}$ & $6.81^{\mathrm{d}}$ & $6.15^{c}$ & $15.20^{\mathrm{f}}$ & $5.30^{\mathrm{b}}$ & $9.91^{\mathrm{e}}$ & $9.96^{\mathrm{e}}$ & nd \\
\hline 11 & Clay $(\%)$ & $28.68^{c}$ & 37.2 de & $36.35^{\mathrm{d}}$ & $25.16^{b}$ & $28.62^{c}$ & $21.87^{\mathrm{a}}$ & $37.88^{\mathrm{e}}$ & nd \\
\hline 12 & Sand $(\%)$ & $42.21^{\mathrm{e}}$ & $31.5^{\mathrm{b}}$ & $33.29^{c}$ & $38.43^{\mathrm{d}}$ & $42.74^{\mathrm{f}}$ & $46.2^{g}$ & $27.12^{\mathrm{a}}$ & nd \\
\hline 13 & $\mathrm{~K}(\mathrm{ppm})$ & $38^{\mathrm{d}}$ & $102^{a b}$ & $297^{c}$ & $052^{\mathrm{a}}$ & $137^{\mathrm{b}}$ & $292^{c}$ & $247^{c}$ & nd \\
\hline 14 & Organic Matter (\%) & $4.91^{\mathrm{c}}$ & $2^{a}$ & $8.6^{\mathrm{e}}$ & $6.72^{\mathrm{d}}$ & $2.41^{\mathrm{a}}$ & $3.55^{\mathrm{b}}$ & $4.32^{b c}$ & nd \\
\hline 15 & $\mathrm{pH}$ & $7.47^{a b}$ & $7.2^{\mathrm{a}}$ & $8.36^{\mathrm{e}}$ & $7.92^{\mathrm{cd}}$ & $8.1^{\mathrm{de}}$ & $8.01^{\mathrm{cd}}$ & $7.71 \mathrm{bc}$ & nd \\
\hline 16 & Total limestone (\%) & $35.21^{\text {a }}$ & $50^{\mathrm{cd}}$ & $34.4^{\mathrm{a}}$ & $44.00^{b c}$ & $53.19^{d}$ & $39.42^{a b}$ & $49.68^{\mathrm{cd}}$ & nd \\
\hline 17 & Active limestone (\%) & $8.46^{\mathrm{a}}$ & $30.7^{\mathrm{d}}$ & $11.74^{\mathrm{ab}}$ & $18.51^{b c}$ & $21.96^{\mathrm{c}}$ & $14.51^{\mathrm{abc}}$ & $20.62^{c}$ & nd \\
\hline
\end{tabular}

Bioclimatic zones were defined according to [38] coefficient. SSACW: Superior semi-arid at cool winter, SHCW: Sub-humid at cool winter, MSACW: Medium semi-arid.

\subsection{Morphological Variation}

The difference between seven $M$. tunetana accessions is statistically significant $(p<0.05)$ for eleven morphological traits as shown in Table 2. The highest morphological traits values relating to leaves, pods and seeds are obtained in MT3 from Kesra with an average of $17.06 \mathrm{~mm}$ of LL, $8.91 \mathrm{~mm}$ of PoW and 3.01 of SL followed by MT4 from Sekiet Sidi Youssef and MT1 from Bargou. 
Table 2. Mean value of eleven morphological traits for six $M$. tunetana populations (mm). Means with the same letters are not significantly different (ANOVA, Tukey test at $p<0.05$ ); nd: not determined.

\begin{tabular}{ccccccccc}
\hline $\mathbf{N}^{\circ}$ & Traits & MT1 & MT2 & MT3 & MT4 & MT5 & MT6 & MT7 \\
\hline 1 & LL $^{* *}$ & $12.00^{\mathrm{a}}$ & nd & $17.06^{\mathrm{b}}$ & $14.94^{\mathrm{ab}}$ & $11.62^{\mathrm{a}}$ & nd & nd \\
2 & LW $^{* * *}$ & $4.50^{\mathrm{a}}$ & nd & $6.75^{\mathrm{b}}$ & $6.31^{\mathrm{b}}$ & $3.31^{\mathrm{a}}$ & nd & nd \\
3 & PL & 8.00 & nd & 7.06 & 7.87 & 5.00 & nd & nd \\
4 & PeL & 1.69 & nd & 1.87 & 1.69 & 1.25 & nd & nd \\
5 & StL & $7.06^{\mathrm{a}}$ & nd & $7.31^{\mathrm{b}}$ & 7.31 & 5.69 & nd & nd \\
6 & PoL $^{* *}$ & $3.64^{\mathrm{a}}$ & nd & $4.98^{\mathrm{b}}$ & $3.51^{\mathrm{a}}$ & $4.40^{\mathrm{ab}}$ & nd & nd \\
7 & POW $^{* * *}$ & $6.04^{\mathrm{a}}$ & nd & $8.91^{\mathrm{c}}$ & $6.81^{\mathrm{b}}$ & $6.04^{\mathrm{a}}$ & nd & nd \\
8 & NPT $^{* * *}$ & $4.24^{\mathrm{b}}$ & nd & $3.33^{\mathrm{k}}$ & $2.60^{\mathrm{a}}$ & $2.70^{\mathrm{a}}$ & nd & nd \\
9 & SL $^{* * *}$ & $2.73^{\mathrm{b}}$ & nd & $3.01^{\mathrm{c}}$ & $2.63^{\mathrm{ab}}$ & $2.55^{\mathrm{a}}$ & nd & nd \\
10 & SW $_{11}$ & 1.91 & nd & $2.07^{\mathrm{b}}$ & 2.08 & 1.99 & nd & nd \\
11 & ST $^{* * *}$ & $1.08^{\mathrm{b}}$ & nd & $1.06^{\mathrm{b}}$ & $0.84^{\mathrm{a}}$ & $0.86^{\mathrm{a}}$ & nd & nd \\
\hline
\end{tabular}

LL: Leaflet Length, LW: Leaflet Width, PL: Petiole Length, PeL: Petiolule Length, StL: Stipule Length, PoL: Pod Length, PoW: Pod Width, NPT: Number of Pod Turns, SL: Seed Length, SW: Seed Width, ST: Seed Thickness. ${ }^{* *}$ : significant at the $99 \%$ confidence level; ${ }^{* * *}$ : significant at the $99.9 \%$ confidence level.

\subsection{Canonical Correspondence Analysis}

In order to estimate the relative importance of each eco-geographical trait in M. tunetana accessions distribution, the canonical correspondence analysis (CCA) was determined. Figure 2 demonstrated that $\mathrm{K}$ content and the total and active lime contents (CT, CA) were the most effective factors for the accession's distribution. Two principal clusters are obtained; the first cluster which is characterized by a high $\mathrm{K}$ content level included the accession MT2 from Makthar.The second cluster includes MT3, MT4 and MT5 from Kesra, Sekiet Sidi Youssef and Thala respectively based on the total and active lime content in the soil. Moreover, CCA axis 1 is positively correlated with $\mathrm{K}, \mathrm{pH}$ and Organic matter (OM\%) content and negatively correlated with annual precipitation, longitude, latitude and Sand content (S\%).

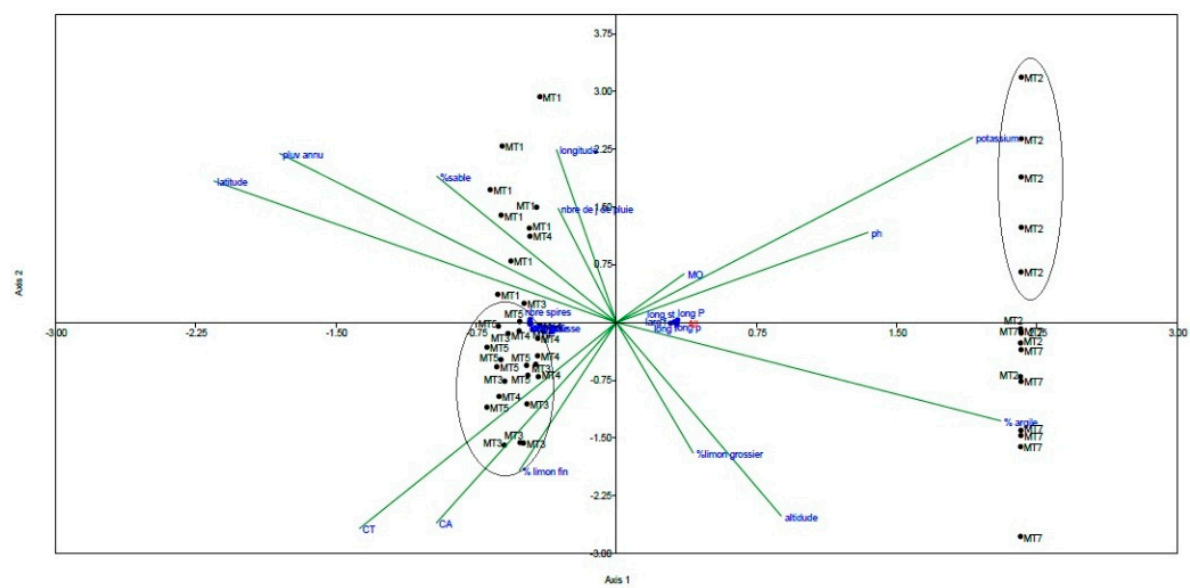

Figure 2. Canonical correspondence analysis (CCA) carried out with eleven morphological data and sixteen eco-geographical traits of seven accessions of M. tunetana collected from different locations of Tunisian ridge.

\subsection{Genetic Diversity Analysis}

The extent of polymorphism in seven accessions of M. tunetana (MT1-7) and a one variety of M. sativa (MS1) were analysed in 20 individuals from each genotype. Among the seven SSR markers used in this study, only five (MTIC82, MTIC338, MTIC343, FMT13 and B14B03) were polymorphic with $M$. tunetana genotypes (Table 3). Allele doses from five microsatellite loci were counted; a total of 54 alleles were detected in the analysed accessions with an average of 10.8 bands per primer and per genotype. 
Table 3. Characterization of five polymorphic microsatellites used in the study of the genetic diversity of M. tunetana and M. sativa accessions.

\begin{tabular}{cccccc}
\hline No. & Markers & $\begin{array}{c}\text { No. of } \\
\text { Alleles }\end{array}$ & $\begin{array}{c}\text { No. of Polymorphic } \\
\text { Bands }\end{array}$ & $\begin{array}{c}\text { Mean } \\
\text { NoBands/Locus }\end{array}$ & PIC \\
\hline 1 & FMT13 & 7 & 5 & 1.4 & 0.21 \\
2 & MTIC338 & 12 & 8 & 1.5 & 0.38 \\
3 & MTIC343 & 19 & 6 & 3.16 & 0.49 \\
4 & MTIC82 & 6 & 4 & 1.5 & 0.26 \\
5 & B14B03 & 10 & 5 & 2 & 0.31 \\
& Total & 54 & 28 & - & - \\
& Mean & 10.8 & 5.6 & 1.19 & 0.33 \\
\hline
\end{tabular}

PIC: Polymorphism Information Content.

The genetic diversity of $M$. tunetana was demonstrated using the observednumber of alleles(na), effective alleles (ne), Shannon's Information index (I) and Nei's gene diversity (h). In fact, a high level of genetic diversity was recorded with an average of effective number of alleles (ne) that ranged between 1.2677 and 1.9231 (Table 4). MT4 genotype from Sekiet Sidi Youssef and MT6 from Thala showed the highest level of effective number of alleles (ne) and Shannon's Information index (I) and Nei's gene diversity (h) with an average of $1.9231,0.48$ and 0.6730 respectively.

Table 4. Genetic variation statistics for all loci. ${ }^{*}$ na $=$ Observed number of alleles; ${ }^{*}$ ne $=$ Effective number of alleles [39]; ${ }^{*} \mathrm{~h}=$ Nei's [40] gene diversity; ${ }^{*} \mathrm{I}=$ Shannon's Information index [41].

\begin{tabular}{ccccc}
\hline Accessions & na & ne $^{*}$ & $\mathbf{I}^{*}$ & $\mathbf{h}^{*}$ \\
\hline MT1 & 2.0000 & 1.6756 & 0.4032 & 0.5930 \\
MT2 & 2.0000 & 1.6756 & 0.4032 & 0.5930 \\
MT3 & 2.0000 & 1.2677 & 0.2112 & 0.3669 \\
MT4 & 2.0000 & 1.9231 & 0.4800 & 0.6730 \\
MT5 & 2.0000 & 1.7705 & 0.4352 & 0.6269 \\
MT6 & 2.0000 & 1.9231 & 0.4800 & 0.6730 \\
MT7 & 2.0000 & 1.5743 & 0.3648 & 0.5511 \\
MS1 & 2.0000 & 1.2677 & 0.2112 & 0.3669 \\
Mean & 2.0000 & 1.6347 & 0.3736 & 0.5555 \\
St. Dev & 0.0000 & 0.2566 & 0.1076 & 0.1234 \\
\hline
\end{tabular}

Genetic distance between pairs of genotypes was estimated using Matrix of Nei's Distance. The largest distance was observed between MT2 and MT5 (0.8000) from Makthar and Thala respectively (Table 5) while the shortest distances were obtained between MT3 and MT7 (0.1278) collected from Kesra and El Ayoun respectively.

Table 5. Nei's original measurements of genetic identity (above diagonal) and genetic distance (below diagonal) [42].

\begin{tabular}{ccccccccc}
\hline Pop ID & MT1 & MT2 & MT3 & MT4 & MT5 & MT6 & MT7 & MS1 \\
\hline MT1 & - & 0.7600 & 0.6000 & 0.5600 & 0.6400 & 0.6400 & 0.4800 & 0.6800 \\
MT2 & 0.2744 & - & 0.6800 & 0.6400 & 0.8000 & 0.6400 & 0.7200 & 0.6800 \\
MT3 & 0.5108 & 0.3857 & - & 0.4800 & 0.7200 & 0.6400 & 0.8800 & 0.7600 \\
MT4 & 0.5798 & 0.4463 & 0.7340 & - & 0.6800 & 0.5200 & 0.5200 & 0.5600 \\
MT5 & 0.4463 & 0.2231 & 0.3285 & 0.3857 & - & 0.6000 & 0.7600 & 0.6400 \\
MT6 & 0.4463 & 0.4463 & 0.4463 & 0.6539 & 0.5108 & - & 0.6800 & 0.4800 \\
MT7 & 0.7340 & 0.3285 & 0.1278 & 0.6539 & 0.2744 & 0.3857 & - & 0.6400 \\
MS1 & 0.3857 & 0.3857 & 0.2744 & 0.5798 & 0.4463 & 0.7340 & 0.4463 & - \\
\hline
\end{tabular}

The dendrogram (Figure 3) presents the genetic relationship between the six M. tunetana accessions (MT1, MT3-7) and the reference variety of M. sativa (MS1) based on the genetic 
similarity coefficients obtained with UPGMA. Obtained results accord to the dendrogram and demonstratethat $57 \%$ of genetic similarity between $M$. tunetana genotypes have defined two clusters, Figure 3.

Group 1 (G1): Formed by two subgroups at $61 \%$ of genetic similarity with other accessions.

Subgroup 1: Formed by MT1 from Bargou and MS1, the variety of M. sativa.

- $\quad$ Subgroup 2: Included four accessions of M. tunetana; MT3, MT5, MT4 and MT7 from Kesra, Thala, Sekiet Sidi Youssef and El Ayoun respectively.

Group 2 (G2): Formed by MT6 from Thala with a 57\% of similarity to other accessions of $M$. tunetana and the reference variety of $M$. sativa.

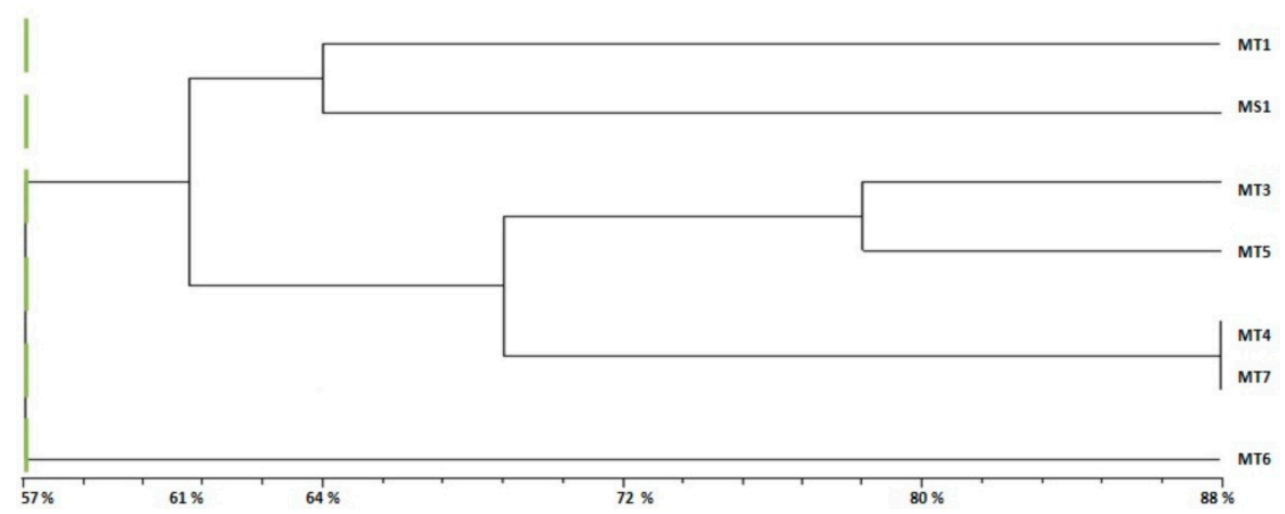

Figure 3. The UPGMA dendrogram based on the analysing of the molecular data by five SSR markers and showing similarity coefficients and genetic relationships among seven accessions of $M$. tunetana and variety of $M$. sativa used as a reference.

\section{Discussion}

M. tunetana had been found in three new prospected sites of the high mountains of Tunisian Dorsal namely Bargou (MT1), El Ayoun (MT7) and Thala (MT5) (Figure 1). These sites were not mentioned in Tunisian flora [43]. It must be noted that annual precipitation is ranging between $522 \mathrm{~mm}$ for Bargou and 299-327 $\mathrm{mm}$ for the others dorsal sites for the last twenty-seven year period (Table 1). For annual average temperature, Makthar presented the lowest value of $19^{\circ} \mathrm{C}$, while the highest value was recorded by the Southern dorsal regions with an average of $20.5^{\circ} \mathrm{C}$ [4]. M. tunetana is native to Western North Tunisia and Algeria. It has many important ecological and agronomical interests including abiotic stress tolerance (cold tolerance, rhizome production and calcareous soil tolerance). These results are consistent with those obtained by El Makki-Ben Brahim et al. [4] who mentioned that the dorsal regions are characterized by a calcareous soil and those of Ferchichi and Rouz [43] who demonstrated that $M$. tunetana genotypes are tolerant to limestone excess in soil. Conservation and management of this rare pastoral genetic resource is an essential preoccupation in order to contribute to the grassland amelioration of the mountains of Western North and Western Centre regions of Tunisia.

In this study, we investigated the genetic diversity of seven wild accessions of $M$. tunetana and local variety of $M$. sativa as reference using seven SSR markers. We obtained 54 different alleles for a sample of 20 plants per accession (Table 3). While Li et al. [20] have obtained just 22 different alleles in M. sativa subsp. falcata populations using the same number of SSR markers for a sample size of 25 plants. Whereas Falahati et al. [29] obtained 68 alleles using eight SSR markers for a sample size of only 10 plants for each accession. Therefore, Julier et al. [44] noted that a sample size of 40 plants is more moderate for tetraploid alfalfa genetic diversity. In fact, these results are consistent with those of Andru [45] who reported that the number of observed alleles is highly dependent on the size of the studied samples. A sample size lower than ten plants gives rise to the loss of even non-rare alleles [44]. The studied M. tunetana genotypes show a large genetic variation with two different groups and two subgroups for only seven accessions (Figure 3) which 
confirms the hypothesis of tetraploidy for this species. The high number of alleles per locus may be explained by the high heterozygosity and allogamy of heterogenous and allogamous genotypes of M. sativa [29]. This result concords with those obtained by Heyn [46] who reported that all perennial species of Medicago genus are auto-tetraploid. Whereas it differs with that obtained by Abdelkefi et al. [47] who mentioned that M. tunetana. is diploid and each gene is presented by only two copies. All forage species are frequently allogamous which makes their genetic card study more complex and difficult to carry out [48]. This allogamy is one of the most important causes of genetic erosion as well as of initial allelic variation loss [49] and obtaining new characters. The observed allogamy in perennial Medicago species may be explained by the gametophytic self-incompatibility which makes getting a pure line so difficult or even impossible [48].

The molecular study for seven $M$. tunetana accessions and local variety of M. sativa using seven SSR markers had showed a large genetic diversity within Medicago genotypes. Two different groups of Medicago accessions were formed based on the generated dendrogram at $57 \%$ of similarity. Gardon et al. [50] showed high degree of variability among M. sativa genotypes with six SSR markers. Cholastova and Knotova [30] demonstrated that the estimation of genetic diversity of Medicago genotypes could be obtained even with only three SSR markers. Based on obtained results, used SSR markers were as efficient to determine genetic variation among the studied $M$. tunetana accessions. This work is the first genetic diversity study of $M$. tunetana genotypes; the number of SSRs used (Table 3) as well as the broad genetic base of $M$. tunetana could be considered not enough. Therefore, this work must be completed by other molecular study using more SSR markers in order to obtain more information about genetic variability of $M$. tunetana and karyotype analysis.

Exsitu conservation of M. tunetana accessions as a Pastoritum or seeds in Gene Bank contributes to this genetic resource conservation as well as in the local alfalfa breeding programs. M. tunetana is an allogamous plant species needing an optimal sample size more than 20 individuals in order to obtain reproducible bands to differentiate between accessions within an active collection. A population sample size lower than 20 individuals could increase the effect of genetic drift which generates loss of biodiversity. Sample size to be conserved in Gene Bank must be surrounding 200 seeds per accession which will allow preserving genetic diversity [51].

\section{Material and Methods}

\subsection{Origin of Plant Material Collection}

In order to collect $M$. tunetana genotypes, many prospecting and collecting missions were carried out by visiting sites reported by Pottier-Alapetite [15] during five years (2015-2020) in the mountains of Western North and Western Centre regions of Tunisia that are located in three different Tunisian governorates (Siliana, Kef and Kasserine) (Table 1).These regions are characterized by a continental climate and generally roughly with an average annual rainfall ranging between $220 \mathrm{~mm}$ and $550 \mathrm{~mm}$ [4].

\subsection{Sample Size}

Six wild accessions of $M$. tunetana were collected for this work. For the morphological study, eight plants from each accession were randomly selected and used. For the genetic analysis, a local variety of $M$. sativa was added to be used as reference. Twenty plants per accession were randomly selected, and green healthy leaves from each plant were chosen for DNA extraction. This study was carried out in the molecular laboratory of National Gene Bank of Tunisia.

\subsection{Ecological Analyses}

The ecological characterization of each prospected site was determined in order to evaluate the most favourable environmental factors (climatic, soil and altitude) for M. tunetana genotypes development. In fact, the annual precipitation and number of rainy days for each prospected site were obtained for twenty-seven years (1992 to 2019) from the 
Ministry of Agriculture, Hydraulic Resources and Fisheries of Tunisia. Therefore, three representative soil samples from each site were taken and had been submitted to four physical analyses (clay $\%$, fine silt $\%$, coarse silt $\%$ and sand $\%$ ) and five chemical analyses $(\mathrm{pH}$, organic matter $\%$, total and active limestone $\%$ and potassium content).

\subsection{Morphological Traits}

M. tunetana accessions variability was examined according to description given by Pottier-Alapetite [15] for its taxonomic classification. The morphological characterization was determined based on 48 samples and six M. tunetana genotypes. Eleven quantitative traits relating to leaves, pods and seeds were measured: leaflet length (LL), leaflet width $(\mathrm{LW})$, petiole length $(\mathrm{PL})$, petiolule length $(\mathrm{PeL})$, stipule length $(\mathrm{StL})$, pod length $(\mathrm{PoL})$, pod width (PoW), number of pod turns (NPT), seed length (SL), seed width (SW) and seed thickness (ST). Data were measured using electronic digital calliper $(0-150 \mathrm{~mm})$ with an accuracy of $0.01 \mathrm{~mm}$.

\subsection{Molecular Analysis}

Genomic DNA was extracted from fresh leaf tissue plants of $M$. tunetana according to the cetyltri-methyl-ammonium bromide (CTAB) technique of [52] with slight modifications. Plant material was ground up in liquid nitrogen, resuspended in $1 \mathrm{~mL}$ of CTAB $2 \times$ buffer and incubated at $60^{\circ} \mathrm{C}$ for $30 \mathrm{~min}$. After chloroform-isoamylic (24:1) extraction, the aqueous phase was collected and the nucleic acid was precipitated with cold isopropanol, then washed with $70 \%$ ethanol and resuspended in $1 \times$ TE buffer after being air-dried. Genetic diversity of different accessions of M. tunetana was evaluated using seven SSR markers identifying QTL genes responsible of the plant height which are positively correlated with forage yield potential in the model species $M$. truncatula [37]. These microsatellites are saved in the databases of EST (expressed sequence tag) and selected by Julier et al. [37] as an efficient marker for molecular characterization of autotetraploid and allogamous plant's Medicago genus (Table 6). The PCR was performed in a final volume of $25 \mu \mathrm{L}$ containing $100 \mathrm{ng}$ of genomic DNA, $0.5 \mu \mathrm{M}$ of each primer pair, $2.5 \mu \mathrm{L}$ of $1 \times$ PCR buffer, $1.5 \mathrm{mM}$ of $\mathrm{MgCl}_{2}, 0.2 \mathrm{mM}$ dNTPs and $0.2 \mu \mathrm{L}$ of Taq DNA polymerase. DNA amplification was performed in a Bio Rad C1000 thermocycler programmed with 35 cycles: 1 cycle for initial Pre-Denaturation at $94{ }^{\circ} \mathrm{C}$ for $4 \mathrm{~min} ; 35$ cycles consist of denaturation at $94{ }^{\circ} \mathrm{C}$ for $1 \mathrm{~min}$, Melting at $\mathrm{Tm}{ }^{\circ} \mathrm{C}$ for $1 \mathrm{~min}$ and extension at $72{ }^{\circ} \mathrm{C}$ for $2 \mathrm{~min} ; 1$ cycle for final extension at $72{ }^{\circ} \mathrm{C}$ for $3 \mathrm{~min}$. PCR products ( $12 \mu \mathrm{L}$ per sample) were separated in $3 \%$ agarose gel at 100 volts constant power for $90 \mathrm{~min}$ and then visualized with BET fluorescence in UV table.

Table 6. SSR primers, their respective sequences, number of alleles and annealing temperature $\left(\mathrm{Ta}{ }^{\circ} \mathrm{C}\right)$.

\begin{tabular}{|c|c|c|c|c|}
\hline No. & Primers & Sequences $5^{\prime}-3^{\prime}$ & Repeated Motif & $\mathrm{Ta}\left({ }^{\circ} \mathrm{C}\right)$ \\
\hline 1 & MTIC451 & $\begin{array}{l}\text { F: CGATCGGAACGAGGACTTTA } \\
\text { R: CCCCGTTTTTCTTCTCTCCT }\end{array}$ & (AAG)6 & 52 \\
\hline 2 & FMT13 & $\begin{array}{l}\text { F: GATGAGAAAATGAAAAGAAC } \\
\text { R: CAAAAACTCACTCTAACACAC }\end{array}$ & (GA)2GG(GA)9 & 52 \\
\hline 3 & MTIC338 & $\begin{array}{c}\text { F: TCCCCTTAAGCTTCACTCTTTTC } \\
\text { R: CATTGGTGGACGAGGTCTCT }\end{array}$ & $(\mathrm{CTT}) 5$ & 56 \\
\hline 4 & MTIC343 & $\begin{array}{c}\text { F: TCCGATCTTGCGTCCTAACT } \\
\text { R: CCATTGCGGTGGCTACTCT }\end{array}$ & $(\mathrm{GAA}) 8$ & 56 \\
\hline 5 & MTIC82 & $\begin{array}{l}\text { F: CACTTTCCACACTCAAACCA } \\
\text { R: GAGAGGATTTCGGTGATGT }\end{array}$ & (TC)11 & 55 \\
\hline 6 & MTIC432 & $\begin{array}{l}\text { F: TGGAATTTGGGATATAGGAA } \\
\text { R: GGCCATAAGAACTTCCACTT }\end{array}$ & $(\mathrm{AG}) 6$ & 55 \\
\hline 7 & B14B03 & $\begin{array}{l}\text { F: GCTTGTTCTTCTTCAAGCTC } \\
\text { R: ACCTGACTTGTGTTTTATGC }\end{array}$ & $(\mathrm{CA}) 9$ & 55 \\
\hline
\end{tabular}




\subsection{Statistical Analysis}

A two-way analysis of variance (ANOVA) was realized for soil analyses and quantitative morphological traits to evaluate difference between means which genotype was the first factor (MT1, MT2, MT3, MT4, MT5, MT6, MT7). Results were statistically significant at $p<0.05$ for Tukey test using the statistical software SPSS statistics version 22.0 (IBM, Armonk, NY, USA).

Morphological, ecological and edaphic traits were examined by a canonical correspondence analysis (CCA) in order to determine the relationship between the analysed traits and the similarity among accessions of $M$. tunetana using PAST software, version 4.03 [53]. The CCA was carried out to the data matrix (11 morphological traits, 6 ecological traits, 10 edaphic traits and 6 genotypes).

For the molecular traits, the bands visualized on the gel were identified to determine whether they were a single allele or just auto-amplification to be discarded. Faint and unreliable bands were not considered for the analysis. Amplified fragments were scored as 1 or 0 for bands presence or absence, respectively. Sizes amplification bands were estimated using DNA Leader 100 pb marker. Genetic distance between accessions was calculated according to Nei [42]. Unweighted pair group method using arithmetic average UPGMA dendrogram were drawn using the SAHN clustering of NTSYSpc 2.10, based on Genetic Distances.

Author Contributions: Conceptualization, Y.F., S.R., A.S. and M.B.N.; methodology, Y.F., A.S., Y.B.M. and S.R.; software, Y.F., M.E. and A.S.; validation, S.R., Z.G.-G. and M.B.N.; formal analysis, investigation, data curation, Y.F., A.S., M.E., Y.B.M., H.B.L. and S.R.; writing—original draft preparation, Y.F. and H.B.L.; writing - review and editing, M.E. and S.R.; funding acquisition, S.R. and M.B.N.; visualization, supervision, S.R. and Z.G.-G. All authors have read and agreed to the published version of the manuscript.

Funding: This research was funded by Laboratory of Agricultural Production Systems and Sustainable Development of the Higher School of Agriculture of Mograne to S.R. and National Gene Bank of Tunisia to M.B.N.

Institutional Review Board Statement: Not applicable.

Informed Consent Statement: Not applicable.

Data Availability Statement: Data are contained within the article.

Conflicts of Interest: The authors declare no conflict of interest.

\section{References}

1. Abdelguerfi, A.; Abdelguerfi-Laouar, M. Les ressources génétiques d'intérêt fourrager et/ou pastoral: Diversité, collecte et valorisation au niveau méditerranéen. Cah. Options Méditerranéennes 2004, 62, 29-41.

2. Boussaid, M.; Ben Fadhel, N.; Zouali, Y.; Ben, S.A.; Abdelkefi, A. Plantes pastorales en milieux arides de l'Afrique du Nord. Cah. Options Méditerranéennes 2004, 62, 55-59.

3. Robert, P.; Thiebeau, P.; Coulmier, D.; Larbre, D. Luzerne et Eau: Mieux Vaut Prévenir Que Guérir; COOP de France Désydratation France: Paris, France, 2010.

4. El Makki-Ben Brahim, N.; Chaabani, A.; Toumi, L.; Sebei, H. Les plantes rares de la Tunisie Septentrionale et central. Ann. l'INRAT 2014, 87, 128-145.

5. Chakroun, M.; Zouaghi, M. Conservation et valorisation des ressources génétiques fourragères et pastorales du Nord Tunisien. PGINA 2004, 123, 46-51.

6. Wang, Z.; Yu, G.; Shi, B.; Wang, X.; Qiang, H.; Gao, H. Development and characterization of simple sequence repeat (SSR) markers based on RNA-Sequencing of Medicago sativa and in silico mapping onto the M. truncatula genome. PLoS ONE 2014, 9, e92029. [CrossRef]

7. Benabderrahim, M.A.; Haddad, M.; Ferchichi, A. Essai d'adaptation de 16 cultivars de luzerne pérenne (Medicago sativa L.) dans un système oasien du sud tunisien: Gabès (local) et 15 cultivars étrangers. Cah. Option Méditerranéenne 2008, 79, 419-422.

8. Gebahrd, C.A.; Buchi, L.; Liebisch, F.; Sinaj, S.; Ramseier, H.; Charles, R. Screening de légumineuses pour couverts végétaux: Azote et adventices. Rech. Agron. Suisse 2013, 4, 384-393. 
9. Tlahig, S.; Ben Khaled, A.; Ben Hmed, L.; Loumerem, M. Evaluation des rendements fourragers et semenciers des progéniteurs d'un polycross des génotypes de luzerne (Medicago sativa L. ssp. sativa) sélectionnées pour les régions arides tunisiennes. Rev. Régions Arid. 2017, 43, 81-88.

10. Tlahig, S.; Yahia, H.; Loumerem, M. Agro-morphological homogeneity of Lucerne (Medicago sativa L. subsp. sativa) half-sib progenies bred for outside oases conditions of southern Tunisia. J. New Sci. 2017, 37, 2031-2034.

11. Aridhi, F.; Sghaier, H.; Gaitanoros, A.; Khadri, A.; Aschi-Smiti, S.; Brouquisse, R. Nitric oxide production is involved in maintaining energy state in Alfalfa (Medicago sativa L.) nodulated roots under both salinity and flooding. Planta 2020, $252,1-7$. [CrossRef] [PubMed]

12. Le Floc'h, E.; Boulos, L.; Vela, E. Catalogue Synonymique Commenté de la FLORE DE TUNISIE; République Tunisienne Ministère de l'Environnement et du Développement Durable Banque Nationale de Gènes: Tunis, Tunisie, 2010.

13. Quiros, C.F.; Bauchan, G.R. The genus Medicago and the origin of the Medicago sativa complex. In Alfalfa and alfalfa improvement. Alfalfa AlfalfaImprov. 1988, 29, 93-124. [CrossRef]

14. Small, E.; Jomphe, M. A synopsis of the genus Medicago (Leguminosae). Can. J. Bot. 1989, 67, 3260-3294. [CrossRef]

15. Pottier-Alapetite, G. Flore de la Tunisie Angiospermes-Dialypétales; Imprimerie Officielle de la République Tunisienne: Tunis, Tunisie, 1979.

16. Catalogue Synonymique Commenté De La Flore De Tunisie. 2010. Available online: https://www.researchgate.net/profile/ Errol-Vela/publication/224023795_Catalogue_Synonymique_Commente_De_La_Flore_De_Tunisie/links/0922b4f8c55746ec4 8000000 / Catalogue-Synonymique-Commente-De-La-Flore-De-Tunisie.pdf (accessed on 15 July 2021).

17. Lesins, K.A.; Lesins, I. Genus Medicago (Leguminosae): A Taxogenetic Study; W. Junk: The Hague, The Netherlands, 1979; 228p.

18. The Plant List (TPL) Site. Available online: http:/ / www.theplantlist.org/tpl1.1/record/ild-8549 (accessed on 15 July 2021).

19. Tharachand, C.; Immanuel Selvarej, C.; Abraham, Z. Molecular Insights into the genetic diversity of Garcinia cambogia Germplasm accessions. Braz. Arch Technol. 2015, 58, 765-772. [CrossRef]

20. Li, P.; Wang, Y.; Sun, X.; Han, J. Using microsatellite (SSR) and morphological markers to assess the genetic diversity of 12 falcata (Medicago sativa spp. falcata) populations from Eurasia. Afr. J. Biotechnol. 2009, 8, 2102-2108.

21. Olivier, L.; Chevalet, C.; Fqoulley, J.L. Utilisation des marqueurs pour la caractérisation des ressources génétiques. Prod. Anim. 2000, 247-252. Available online: https:/ / hal.inrae.fr/hal-02695861 (accessed on 15 July 2021).

22. Roldán-Ruiz, I.; De Riek, J.; Muylle, H.; Baert, J.; Ghesquiere, A.; Vandewalle, M. Les marqueurs moléculaires: Quelles utilisations possibles en cultures fourragères. Fourrages 2005, 183, 419-438.

23. Zaccardelli, M.; Gnocchi, S.; Carelli, M.; Scotti, C. Variation among and within Italian alfalfa ecotypes by means of bio-agronomic characters and amplified fragment length polymorphism analyses. Plant Breed. 2003, 122, 61-65. [CrossRef]

24. Keivani, M.; Ramezanpour, S.; Soltanloo, H.; Choukan, R.; Naghavi, M.; Ranjbar, M. Genetic diversity assessment of alfalfa (Medicago sativa L.) populations using AFLP markers. Aust. J. Crop. Sci. 2010, 4, 491.

25. Litoriya, N.S.; Talati, J.G.; Kher, H.R. Identification of Lucerne (Medicago sativa L.) Varieties Using Randomly Amplified Polymorphic DNA Markers. Indian J. Agric Biochem. 2009, 22, 60-62.

26. Touil, L.; Bao, A.; Wang, S.; Ferchichi, A. Genetic Diversity of Tunisian and Chinese Alfalfa (Medicago sativa L.) Revealed by RAPD and ISSR Markers. Am. J. Plant Sci. 2016, 7, 967-979. [CrossRef]

27. Brouwer, D.J.; Osborn, T.C. Identification of RFLP markers linked to the unifoliolate leaf, cauliflower head mutation of alfalfa. $J$. Hered. 1997, 88, 150-152. [CrossRef]

28. Kidwell, K.K.; Hartweck, L.M.; Yandell, B.S.; Crump, P.M.; Brummer, J.E.; Moutray, J.; Osborn, T.C. Forage yields of alfalfa populations derived from parents selected on the basis of molecular marker diversity. CellBiol. Mol. Genet. 1999, 39, $223-227$. [CrossRef]

29. Falahati-Anbaran, M.; Habashi, A.A.; Esfahany, M.; Mohammadi, S.A.; Ghareyazie, B. Population genetic structure based on SSR markers in alfalfa (Medicago sativa L.) from various regions contiguous to the centers of origin of the species. J. Genet. 2007, 86, 59-63. [CrossRef] [PubMed]

30. Cholastova, T.; Knotova, D. Using Morphological and Microsatellite (SSR) Markers to Assess the Genetic Diversity in Alfalfa (Medicago sativa L.). Int. J. Agric. Biosyst. Eng. 2012, 6, 781-787. [CrossRef]

31. Wang, Z.; Hongwei, H.; Fu, X.; Gao, H. Development of simple sequence repeat markers and diversity analysis in alfalfa (Medicago sativa L.). Mol. Biol. Rep. 2013, 40, 3291-3298. [CrossRef] [PubMed]

32. Shivakumar, M.S.; Ramesh, S.A.; Mohan, R.; Udaykumar, H.R.; Keerthi, C.M. Cross Legume Species/Genera Transferability of SSR Markers and their Utility in Assessing Polymorphism among Advanced Breeding Lines in Dolichos Bean (Lablab purpureus L.). Int. J. Curr. Microbiol. App. Sci. 2017, 6, 656-668. [CrossRef]

33. Wang, H.; Chen, P.; Liu, D. Assessment of genetic diversity of Yunnan, Tibetan and Xinjiang wheat using SSR markers. J. Genet. Genom. 2007, 34, 623-633. [CrossRef]

34. Amouri, A.; Aoul, S.H. Molecular analysis of two genotypes of Medicago truncatula Gaertn. by the expressed sequence tag EST6SSR (MTIC124) in response to salinity. Int. J. Innov. Appl. Stud. 2016, 17, 627-631.

35. Touil, L.; Guesmi, F.; Fares, K.; Zagrouba, C.; Ferchichi, A. Genetic diversity of some Mediterranean populations of the cultivated alfalfa (Medicago sativa L.) using SSR markers. Pak. J. Biol. Sci. 2008, 11, 1923-1928. [CrossRef] [PubMed]

36. Diwan, N.; Bhagwat, A.A.; Bauchan, G.R.; Cregan, P.B. Simple sequence repeat DNA markers in alfalfa and perennial and annual Medicago species. Genomes 1997, 40, 887-895. [CrossRef] 
37. Julier, B.; Flajoulot, S.; Barre, P.; Cardinet, G.; Santoni, S.; Huguet, T.; Huyghe, C. Construction of two genetic linkage maps in cultivated tetraploid alfalfa (Medicago sativa) using microsatellite and AFLP markers. BMC Plant Biol. 2003, 3, 1-19. [CrossRef] [PubMed]

38. Emberger, L. Une classification biogéographique des climats. Recherche et travaux de laboratoire géographique, botanique et zoologie. Fac. Sci. MonpellierFr. 1966, 7, 1-43.

39. Kimura, M.; Crow, J.F. The number of alleles that can be maintained in a finite population. Genetics 1964, 49, 725-738. [CrossRef]

40. Nei, M. analysis of gene diversity in subdivided populations. Proc. Natl. Acad. Sci. USA 1973, 70, 3321-3323. [CrossRef] [PubMed]

41. Lewontin, R.C. The Apportionment of Human Diversity; Committee on Evolutionary Biology, University of Chicago: Chicago, IL, USA, 1972; pp. 381-398. [CrossRef]

42. Nei, M. Genetic distance between populations. Am. Nat. 1972, 106, 283-292. [CrossRef]

43. Ferchichi, Y.; Rouz, S. Effet de l'amendement humique sur l'amélioration des paramètres agronomiques de quelques populations de Medicago tunetana cultivées sous stress abiotique. In Oral Communication in the International Scientific Day of Mograne 'Sustainable Management of Natural Resources'; Higher School of Agriculture of Mograne: Mograne, Tunisia, 2017; p. 10.

44. Julier, B.; Herrmann, D.; Flajoulot, S.; Barre, P.; Huyghe, C.; Ronfort, J. Structuration de la diversité génétique chez la luzerne cultivée, conséquence pour l'identification de gènes liés à des caractères agronomiques. Innov. Agron. 2014, $35,13-18$.

45. Andru, J. Les Populations Invasives de Rongeurs en Milieu Agricole: Une Etude Menée Dans des Cultures de Grande Echelle, les Plantations de Palmiers à Huile en Indonésie-Approche Paysagère, Génétique et Ecotoxicologique, Thèse de Doctorat en Sciences-Santé; Université Claude Bernard Lyon: Lyon, France, 2012.

46. Heyn, C.C. The Annual Species of Medicago. Scripta Hierosolymitana; University of Jerusalem: Jerusalem, Israel, 1963.

47. Abdelkefi, A.; Boussaid, M.; Djemal, F.; Cherifi, K.; Marrakchi, M. Approche analytique de la variabilité chez deux espèces spontanées du genre Medicago. In Oral Communication, Soc. Tun. Chim. Biol.; Monastir, Tunisie, 1990.

48. Julier, B.; Bare, P. Les cartes génétiques chez les espèces fourragères pérennes des régions tempérées. Fourrages 2005, 183, 389-403.

49. Havananda, T.; Charles Brummer, E.; Doyle, J. Complex patterns of autopolyploid evolution in alfalfa and allies (Medicago sativa; Leguminosae). Am. J. Bot. 2011, 98, 1-14. [CrossRef]

50. Gardon, N.G.; Alarcon, Y.; Moreno, M.V.; Arolfo, V.; Orodizzi, A.; Basigalup, D.H.; Gieco, J.O.; Bruno, C.I. Genetic diversity among alfalfa genotypes (Medicago sativa L.) of non-dormant cultivars using SSR markers and agronomic traits. Rev. FCA UNCUYO 2013, 45, 181-195.

51. Rouz, S.; Ben Jeddi, F.; Zouaghi, M.; Ghrabi-Gammar, Z. Diversité Génétique des Accessions de Bersim (Trifolium alexandrinum L., Fabaceae) par la Technique SDS PAGE. Revue de l'I.N.R.A.T. 2012, 27, 145-161.

52. Saghai-Maroof, M.A.; Soliman, K.M.; Jorgensen, R.A.; Allard, R.W. Ribosomal DNA sepacer-length polymorphism in barley: Mendelian inheritance, chromosomal location, and population dynamics. Proc. Natl. Acad. Sci. USA 1984, 81, 8014-8019. [CrossRef] [PubMed]

53. Hammer, O.; Harper, D.A.T.; Rayan, P.D. Past: Palaeontogical statistics software package for education and data analysis. Palaeontol. Electron. 2011, 4, 9. 